\title{
Improving Self-Resilience in Students with Special Needs through the Counseling Teachers' Roles: A Case Study on Grounded Theory
}

\author{
Beni Azwar $\mathbb{D}^{1},{ }^{1}$ Deri Wanto ${ }^{(D)}{ }^{2}$ and Rahmad Hidayat ${ }^{3}{ }^{3}$ \\ ${ }^{1}$ Study Program of Islamic Education Guidance and Counseling, Faculty of Tarbiyah, IAIN Curup, Rejang Lebong, Indonesia \\ ${ }^{2}$ Study Program of Islamic Education, Faculty of Tarbiyah, IAIN Curup, Rejang Lebong, Indonesia \\ ${ }^{3}$ Study Program of Islamic Education Guidance and Counseling, Postgraduate Program, IAIN Curup, Rejang Lebong, Indonesia
}

Correspondence should be addressed to Deri Wanto; deriwanto@iaincurup.ac.id

Received 8 October 2021; Accepted 30 October 2021; Published 23 November 2021

Academic Editor: Ehsan Namaziandost

Copyright ( $\odot 2021$ Beni Azwar et al. This is an open access article distributed under the Creative Commons Attribution License, which permits unrestricted use, distribution, and reproduction in any medium, provided the original work is properly cited.

Previous studies show that self-resilience was significantly improved in students with special needs by supporting the social environment and the learning system. Additionally, support for the role of counseling teachers in inclusive schools fosters selfresilience. In this regard, this study aimed to understand the role of counseling teachers foster self-resilience among students with special needs in inclusive schools. The grounded theory approach was applied to produce theories related to these issues. The participants included eleven counseling teachers and the special needs students drawn from three schools in West Sumatra and Bengkulu, Indonesia. The data collected were analyzed based on three stages of grounded analysis, including open coding, axial coding, and selective coding. The findings indicated that self-resilience among students with special needs grows when the counseling teachers use three roles, namely, modifying behavior, giving instructions repeatedly and providing options according to students' interest.

\section{Introduction}

Students with special needs have abilities that can be developed and nurtured through an inclusive school approach [1]. However, their success heavily relies on the commitment of teachers to ensure the students get everything they need. Among the crucial aspects that teachers should develop include self-independence (self-resilience). Various studies show that self-resilience for this kind of student not only supports academic performance but also enables them to have a better life [2].

Harðardottir et al. [3] conducted a study related to resilience in learning difficulties among students with special needs. It identified that promoting the growth of selfresilience in students with special needs results in success in education [3]. Parker and Folkman [4] identified strategies that can be used by teachers, instructors, and even administrative staff to teach. In this regard, the study offered several approaches to help students with special needs, including strength-based approach, classroom-level strategies, and school-level strategies. However, each approach depends on objective conditions, such as the relevant soft skills worth developing in special needs students.

Fernandes et al. confirmed that soft skills differ from one student to another. Therefore, teachers must fully understand the strengths and weaknesses of the students they teach [5]. Bouillet and Kudek Mirosévic emphasized the importance of additional support in the learning process. This implies that a teacher's soft skills depend on the students' contextual and objective needs [6]. Various existing studies show that self-resilience and soft skills improvement in students with special needs are two important factors. However, these two do not necessarily ignore the role of a counseling teacher.

Nevertheless, less number of literature studies discusse the role of counseling teachers in the growth of self-resilience among students with special needs, specifically in inclusive schools. Hence, this study seeks to fill this gap and explicitly elaborate on the role of counselors in increasing student selfresilience in inclusive schools. SMA Muhammadiyah Curup, 
MAN 2 Payakumbuh, and SMK 2 Bukittinggi schools were chosen for this study. This choice is based on the assumption that the three upper secondary schools are educational institutions that emphasize equal opportunities for all.

Furthermore, this study is divided into various sections, including the Introduction that elaborates the gaps and formulation of the novelty offered in this study and the Literature Review section, which reviews the self-resilience concept in students with special needs concerning increasing self-resilience. Section 3 reviews how grounded theory is applied as a method, while Sections 4 and 5 describe the results and interpretation of the findings. Finally, the Conclusion section reaffirms the crucial findings and the limitations of the study, which other social scholars can then re-examine.

\section{Literature Review}

Studies related to teaching children with special needs have been widely published and continue to grow massively. However, the issues studied are evolving, implying they are discussed from various perspectives. Algahtani succeeded in explaining intellectual disabilities and their relation to teaching strategies with the help of constructivism and behaviorism perspectives. This study provides recommendations for teaching students with intellectual disabilities [6]. The first recommendation involves breaking down the activities into small parts since students cannot easily absorb a single or complex topic. Therefore, it is appropriate to divide the materials into sections to be taught at a time. Second, model, illustrate, and explain every step when teaching new activities. This will not only make the information clear but also enable students to remember what they learned. Furthermore, students are more likely to remember concepts taught using models or illustrations than without them. Third, using rewards (appreciating the learners with nice messages and offering them physical gifts such as sweets, toys, and more) to reinforce appropriate learning behavior from the students. Fourth, use additional practice and assessment as much as possible to ensure complete mastery of concepts. Students should also be allowed to replicate simple models made by the teacher. This will ensure that they learn and practice various concepts simultaneously [7].

Sakellariou et al. conducted a study on the role of social skills in learning in inclusive schools, with special needs students as objects of teaching. Generally, students with special needs have difficulty in learning social skills such as communication, solving problems, and behavior management. Therefore, there is a need to apply a holistic approach to improve social skills [2]. Bouillet and Kudek Mirošević identified that students with special needs require exceptional support in many aspects, including learning process and adequately implemented school policies to help the students obtain good academic grades [6]. This means success in the learning process and academic achievement of these students is cultural and requires teachers to apply dynamic and contextual learning strategies.
Katsafanas also examined other factors that play an essential role in determining the success of children with special needs, specifically in their learning endeavors. Katsafanas observed that teaching learners with special needs has many challenges, specifically in imparting knowledge. However, the more the teachers interact with the special needs students, the more they gain experience, which leads to overall success in learning [8]. Contrarily, the theory formulated by Campbell-Whatley [9] suggested that students with special needs will effectively develop themselves when they are promoted to recognize and realize their shortcomings. In regard with this, a teacher should only cultivate self-determination skills and self-concept in the learners.

Various existing studies do not specifically describe the role of counseling teachers in increasing the self-resilience in students with special needs. Therefore, this study seeks to contribute towards the role of counseling teachers for students with special needs to promote the growth and development of self-resilience among students with special needs through qualitative identification.

There is a set of supporting factors to accelerate the academic performance of students with special needs, including emphasizing learning strategies [7], applying a holistic approach [2], inclusive schools policy [6], and teachers' rules $[8,9]$. However, the recent studies ignored the other essential factors, such as the role of Counseling Teachers in inclusive schools. This factor is an influential variable, which essentially determines the enormous academic performance of students with special needs. In this regard, this study aims to elaborate qualitatively on how the role of Counseling Teachers in inclusive schools determines the special needs students' self-resilience. The novelty of this study was anchored in two formulations, namely, the Counseling Teachers' role, which was believed to be the influential factor determining the self-resilience of special needs students, and the location of the study (three schools in two provinces-West Sumatra and Bengkulu). In addition, these schools were categorized as inclusive educational institutions where all students learn and are facilitated by the Counseling Teachers.

\section{Method}

This study applies a qualitative approach using design grounded theory. Pulla (2016) emphasized finding a theory from data collected through qualitative instruments [10]. Khan observed that grounded theory emphasizes conceptual thinking and theory building rather than empirical theory testing [11]. This confirms the interpretive aspect of the data and the naturalistic approach used to address the issue under study. This study used the grounded theory approach because of some reasons, including the role of the counseling teacher to increase self-resilience in students with special needs at SMA Muhammadiyah Curup. In this context, the role of a counseling teacher cannot be quantified but can be understood. Therefore, it is necessary to understand how a teacher builds the process of promoting self-resilience in students with special needs. 
3.1. Study Participants and Data Collection. Study subjects are informants believed to have mastered the information and provide the data required for the study. The informant is the person who has the data that is not permanently attached to them. Generally, informants consist of those who are incharge, implementers, counseling guidance teachers, students with special needs, and subject teachers. Sampling was voluntary as this was necessary to build natural interactions without coercion. Miles \& Huberman [12] observed that this technique does not use random regions or strata but considers and focuses on specific goals. The considerations in using this method include sampling with characteristics or characters with the main characteristics of the population. Also, the subject is a sample with characteristics in the population (key subjects), and the characteristics of the population must be chosen carefully.

3.2. Data Analysis. The data analysis model applied in this study involves the grounded theory design. Khankeh et al. explained that data analysis in grounded theory design applies constant comparative analysis throughout its collection [13]. In this context, data analysis was carried out at three levels of analysis, namely, open coding, axial coding, and selective coding (see Figure 1). It can be illustrated as follows.

A shared coding plan was used during the open coding phase, while vivo coding was built from interview transcripts. Furthermore, axial coding was useful in establishing the relationship between various categories and subcategories. The selective coding phase is built through "the saturation of concepts," categories, and subcategories to define and find relationships between various categories and main categories [12].

\section{Results}

This study was conducted at three schools (SMA Muhammadiyah Curup, MAN 2 Payakumbuh, and SMKN 2 Bukittinggi) within two provinces (West Sumatra and Bengkulu) in Indonesia believed to fulfill the criteria for inclusive schools. The salient criteria that favored the inclusion of these schools included the schools having adequate facilities in the form of teachers and counseling guidance teachers for students with special needs.

Table 1 informs the variation of participants in the three high schools in West Sumatra Province. Three participants were selected on a voluntary basis as informants, the group counseling teachers, subject teachers (teacher), and students with disabilities. This variety of participants was chosen to express an understanding of how the role of teachers, specifically counseling guidance teachers in inclusive schools, promotes the growth of self-resilience among students with special needs. Also, such a variation is necessary for studies with a grounded theory approach to build a qualitative model that can explain specific issues [14].

Table 2 informs the categories and subcategories involved in the coding from the empirical data collected. Categories have a broader dimension comprising characteristics as a concept and "subcategories" that explain and have a strong relationship with categories. In this case, the category identified from the empirical data refers to the role of the counseling teacher in promoting the growth of self-resilience in students with special needs through three roles, including modifying behavior by balancing logic and feelings (revealed by participant number 4 with a match level of information reaching 58.15\%). The counseling teacher cultivates patience and perseverance in students with special needs, as revealed by participant number 11, with information conformity to the subcategories attaining $83 \%$. The other subcategory refers to behavior modification through "motivating" and "not punishing." This means that counseling teachers promote the growth of self-resilience by motivating the students than administering punishment. This was revealed by participant numbers 6,9 , and 10 with coverage information percentages of $16.86 \%, 36.50 \%$, and $35.28 \%$, respectively.

The second category is "consistently giving instruction," with two subcategories. The first subcategory involves repeating the subject where the counseling teacher patiently repeats the learning material to enable special needs students to understand well. Participants 1 and 8 revealed this, with percentages coverage reaching $12.98 \%$ and $88.81 \%$, respectively. The second subcategory refers to "teach with signs." This implies that the counseling teachers communicate with special needs students, specifically those who are deaf, using their lips. This information was disclosed by participant number 5 , with a level of coverage of $83.24 \%$. The last category is "giving choices," which means that counseling teachers give students with special needs various choices to choose subjects based on their areas of interest. However, the choice must also be based on the student's academic performance subcategory. This was revealed by participant number 3 , with $57.45 \%$ as the level of information coverage. In general, the role of the counseling teacher in increasing the self-resilience in students with special needs is represented through modifying student behavior, consistently giving instructions, and providing a choice of things to be developed based on the students' interest. These three factors promote the growth of an attitude of self-resilience among students with special needs.

\section{Discussion}

Cultivating self-resilience in students with special needs is quite challenging compared to imparting it to other learners. This is because students with special needs take time to grasp what is taught at school [2]. Therefore, a specific strategy is needed to foster self-resilience among students with special needs. Zeleke, for example, observed that shaping the personality of students with special needs largely depends on the ability to build self-concept [16]. Mustafa-Alsheikh et al. identified that growing self-reliance among students with special needs requires a dynamic, conditional strategy [17]. This means that fostering self-resilience in students with special needs is determined by the setting where the learning process takes place. 


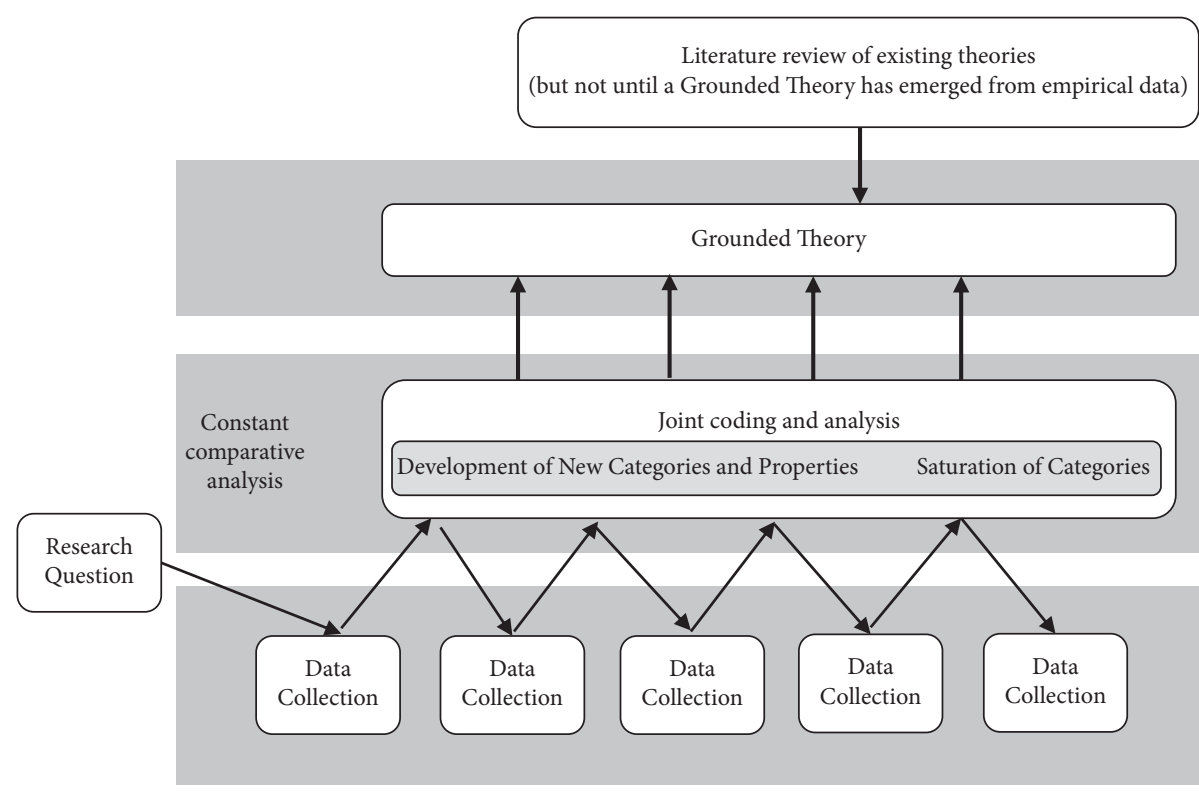

Source: (Wagner et al., 2010)

Figure 1: The basic process of the grounded theory approach. Source: [15].

TABLE 1: Research participants.

\begin{tabular}{lccc}
\hline Participants number & Gender & Schools name & Status \\
\hline 1 & F & SMA Muhammdiyah, Curup & The counseling teacher \\
2 & M & SMA Muhammdiyah, Curup & The disabled-student \\
3 & F & SMA Muhammdiyah, Curup & The counseling teacher \\
4 & F & SMKN 2 Bukittinggi & The counseling teacher \\
5 & M & MAN 2 Payakumbuh & Teacher \\
6 & M & SMA Muhammadiyah, Curup & The counseling teacher \\
7 & M & MAN 2 Payakumbuh & The disabled-student \\
8 & F & SMA Muhammadiyah, Curup & The counseling teacher \\
9 & S & SMA Muhammadiyah, Curup & The counseling teacher \\
10 & F & MAN 2 Payakumbuh & The counseling teacher \\
11 & F & MAN 2 Payakumbuh & The counseling teacher \\
\hline
\end{tabular}

Source: author's own.

TABLE 2: Categories and subcategories of the counseling teacher's role.

\begin{tabular}{lccc}
\hline Categories & Subcategories & $P$ & Coverage \\
\hline & Balancing logic and feeling & 4 & $58.15 \%$ \\
& Cultivating patience and perseverance & 11 & $83 \%$ \\
Behaviour modification & & 10 & 10 \\
& Motivating not punishing & 6 & $95.28 \%$ \\
& & 9 & $18.56 \%$ \\
& & 1 & $36.86 \%$ \\
Consistently giving instruction & Repeating the subject & 5 & $12.98 \%$ \\
Giving choices & Teach with signs & $38.81 \%$ \\
\hline
\end{tabular}

Source: author's own.

Bucholz and Sheffler emphasized the importance of creating an inclusive and welcoming classroom environment to promote the growth of the self-resilience attitude among students with special needs [18]. Once the special needs students are accepted as part of the general community, bullying, which slows down their academic progress, and as a result, they begin to socialize normally [19]. Therefore, an interactive, nondiscriminatory, and inclusive classroom environment is needed for the growth of students with special needs. Adefila et al. also observed that students with 


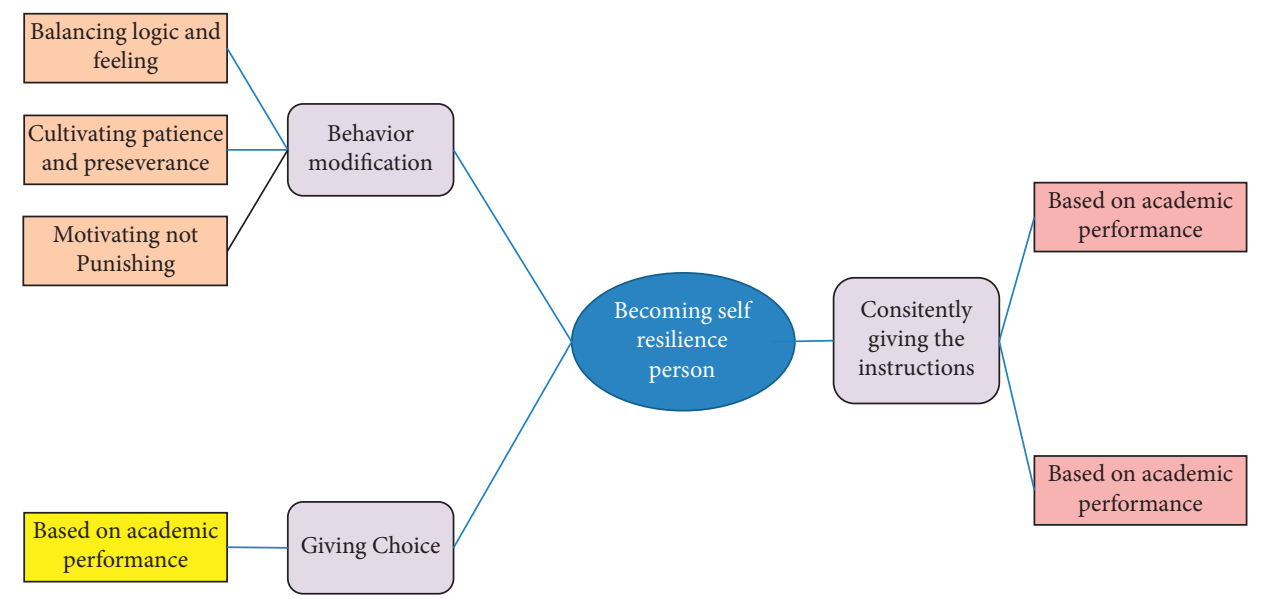

FIGURE 2: The role of counseling teachers in fostering self-resilience of the special needs students. Source: author's own.

special needs could achieve academic excellence, while schools grow a self-resilience attitude [20]. This is undoubtedly determined by the environmental support, teachers, and facilities that can support the growth of selfresilience.

Sharma et al. [21] also confirmed that empathy and support given by peers greatly determine academic performance among students with special needs. This also confirms the view that strong support from the environment, including peers, can convincingly promote and support the growth of self-resilience and self-confidence among students with special needs. Furthermore, a study conducted by Seale et al. provided a broader view that access to social and cultural resources helps students with special needs to individually cultivate a self-resilience attitude in life [22]. However, these findings are different from the results carried out through the grounded theory approach, where efforts to foster self-resilience among students with special needs are highly dependent on the role played by counseling teachers in inclusive schools.

Figure 2 informs and provides a theoretical formulation offered in this study. Theoretically, it confirms that the role of counseling teachers in fostering self-resilience in students with special needs can be conducted through the enactment of three categories. The first category is about behavior modification, which has various subcategories, including balancing logic and feelings, promoting the growth of patience and perseverance, and emphasizing motivation and not punishment. The second category involves consistently giving the instructions, with subcategories such as repeating material or lessons and teaching with the help of gestures. The third category is giving a choice, with the subcategory of choices related to subjects, but still paying attention to academic performance in existing subjects. The three roles of the counseling teacher are believed to foster self-resilience among students with special needs. The empirical findings of this study show that the role of counseling teachers in inclusive schools is vital and has a significant impact in promoting self-resilience among students with special needs.

\section{Conclusion}

This study contributes to developing theories regarding how students with special needs become self-resilient both in the learning process and in life. Through grounded theory approach, it has identified that self-resilience through the role of counseling teachers in inclusive schools can be realized. The role of counseling teachers in inclusive schools is divided into three categories, including behavior modification, consistently giving instructions, and giving a choice. Furthermore, these categories have six subcategories of balancing logic and feeling: cultivating patience and perseverance, motivating, not punishing, repeating the subject, and teaching with a cue, and based on academic performances.

6.1. Implications. This study indicates a challenge for educational institution stakeholders to improve the role of counseling teachers to help to cultivate self-resilience among students with special needs. In this regard, formulating a set of policies that systematically organize the roles of counseling teachers is necessary. The counseling teachers will comfortably and confidently carry out their duties, while educational stakeholders such as the principals provide support to them through the formulation of strategic design that counseling teachers can apply to foster self-resilience among special needs students. However, the strategic design should be dynamic and flexible to enable the counseling teachers to improvise methods to foster self-confidence and self-resilience.

6.2. Limitations and Future Research. Although the study succeeded in confirming the importance of the role of counseling teachers in fostering self-resilience, it has some limitations. For instance, other factors could not be verified apart from the role of counseling teachers in fostering selfresilience among students with special needs in inclusive schools. In this regard, future studies can examine how other factors and the role of counseling teachers influence the 
success of fostering self-resilience among special needs students in inclusive schools in Indonesia.

\section{Data Availability}

The datasets generated and/or analysed during the current study are available from the corresponding author on reasonable request.

\section{Conflicts of Interest}

The authors declare that there are no conflicts of interest.

\section{Acknowledgments}

The authors appreciate all the participants who were voluntarily willing to become informants and provided the data needed for the study, specifically the principals of SMA Muhammadiyah Curup, MAN 2 Payakumbuh, and SMKN 2 Bukittinggi.

\section{References}

[1] J. Buli-Holmberg and S. Jeyaprathaban, "Effective practice in inclusive and special needs education," International Journal of Special Education, vol. 31, no. 1, pp. 119-134, 2016.

[2] M. Sakellariou, P. Strati, and R. Anagnostopoulou, "The role of social skills throughout inclusive education implementation," East African Scholars Journal of Education, Humanities and Literature, vol. 2, no. 10, pp. 633-641, 2019.

[3] S. Harðardóttir, S. Júlíusdóttir, and H. S. Guðmundsson, "Understanding resilience in learning difficulties: unheard voices of secondary school students," Child and Adolescent Social Work Journal, vol. 32, no. 4, pp. 351-358, 2015.

[4] J. Parker and J. Folkman, "Building resilience in students at the intersection of special education and foster care: challenges, strategies, and resources for educators," Issues in Teacher Education, vol. 24, no. 2, pp. 43-62, 2015.

[5] P. R. Fernandes, J. Jardim, and M. C. D. D. Lopes, "The soft skills of special education teachers: evidence from the literature," Education Sciences, vol. 11, no. 3, p. 125, 2021.

[6] D. Bouillet and J. Kudek Mirošević, "Students with Disabilities and Challenges in Educational Practice/Učenici s teškoćama i izazovi obrazovne prakse," Croatian Journal of EducationHrvatski časopis za odgoj i obrazovanje, vol. 17, 2015.

[7] A. Faris, "Teaching students with intellectual disabilities: constructivism or behaviorism?" Educational Research and Reviews, vol. 12, no. 21, pp. 1031-1035, 2017.

[8] J. D. Katsafanas, The Roles and Responsibilities of Special Education Teachers, University of Pittsburgh, Pittsburgh, PA, USA, 2006.

[9] G. D. Campbell-Whatley, "Teaching students about their disabilities: increasing self-determination skills and selfconcept," International Journal of Special Education, vol. 23, no. 2, pp. 137-144, 2008.

[10] V. Pulla, "An introduction to the grounded theory approach in social research," International Journal of Social Work and Human Services Practice, vol. 4, no. 4, pp. 75-81, 2016.

[11] S. N. Khan, "Qualitative research method: grounded theory," International Journal of Business and Management, vol. 9, no. 11, 2014.
[12] M. B. Miles and A. M. Huberman, Qualitative Data Analysis: An Expanded Sourcebook, SAGE Publications, Thousand Oaks, CF, USA, 1994.

[13] H. R. Khankeh, S. A. Hosseini, L. Rezaie, J. Shakeri, and D. C. Schwebel, "A model to explain suicide by self-immolation among Iranian women: a grounded theory study," Burns, vol. 41, no. 7, pp. 1562-1571, 2015.

[14] A. Bryant and K. Charmaz, The SAGE Handbook of Grounded Theory, A. Bryant and K. Charmaz, Eds., SAGE Publications Ltd, Thousand Oaks, CF, USA, 2007.

[15] S. M. Wagner, P. Lukassen, and M. Mahlendorf, "Misused and missed use - grounded Theory and Objective Hermeneutics as methods for research in industrial marketing," Industrial Marketing Management, vol. 39, no. 1, pp. 5-15, 2010.

[16] S. Zeleke, "Self-concepts of students with learning disabilities and their normally achieving peers: a review," European Journal of Special Needs Education, vol. 19, no. 2, pp. 145-170, 2004.

[17] G. Y. Mustafa-Alsheikh, A. I. M. Allan, and N. D. Sulaiman, "Development of student's self reliance and decision making during study in Tikrit University College of Medicine," The Medical Journal of Tikrit University, vol. 45, no. 5, pp. 117-122, 1999.

[18] J. L. Bucholz and J. L. Sheffler, "Creating a W eating a Warm and Inclusive arm and Inclusive Classr e Classroom Envir oom Environment: planning onment: planning for All Children to Feel Welcome," Electronic Journal for Inclusive Education, vol. 2, no. 4, pp. 1-13, 2009.

[19] B. Huang, H. Lu, and R. Zhu, "Disabled peers and student performance: quasi-experimental evidence from China," Economics of Education Review, vol. 82, Article ID 102121, 2021.

[20] A. Adefila, C. Broughan, D. Phimister, and J. Opie, "Developing an autonomous-support culture in higher education for disabled students," Disability and Health Journal, vol. 13, no. 3, Article ID 100890, 2020.

[21] N. Sharma, V. Pratap Yadav, and A. Sharma, "Attitudes and empathy of youth towards physically disabled persons," Heliyon, vol. 7, no. 8, Article ID e07852, 2021.

[22] J. Seale, J. Georgeson, C. Mamas, and J. Swain, "Not the right kind of 'digital capital'? An examination of the complex relationship between disabled students, their technologies and higher education institutions," Computers \& Education, vol. 82, pp. 118-128, 2015. 